\title{
Factors Affecting procurement Performance in Public Institutions in Kenya: Asurvey of Public Institutions in Kisii County
}

\author{
Joshua Nyaribo Okong'o ${ }^{1,}$ Dr. Willy Muturi ${ }^{2}$ \\ ${ }^{1}$ Jomo Kenyatta University of Agriculture and Technology Department of Procurement and Logistics, Nairobi, \\ Kenya \\ ${ }^{2}$ Jomo Kenyatta University of Agriculture and Technology, Kenya
}

\begin{abstract}
Procurement is the nerve centre of performance in every institution, whether public or private and thus needs a tight system to be followed and adopted.This research study therefore sought to assess the factors affectingprocurementperformance in Public institutions in Kisii County. The study examined at examining how procurement planning and politicalinterference affect Public procurement performance of the Public institutions. The study employed a descriptive research design. The target population was 214 users in procurement department and suppliers of the public institutions in Kisii County. A survey questionnaire was developed and employed to collect data from the 54 respondents besides secondary data being used. Data analysis was done using descriptive statistics such as percentages and inferential statistics and presented in tables and figures. The findings of this study revealed that most public institutions have a procurement plan prepared annually and the political class is not supportive of procurement systems. This study recommends that for public procurement to be effective in the public institutions: the National Treasury and public institutions should organize regular skills upgrading courses on public procurement; the procurement plan should be prepared on time and strict adherence to it;management should as a matter of urgency support the procurement department by allocating moreand the procurement staff should be independent in the exercise of their mandate. Keywords: Procurement Planning, Political Interference, Kenya
\end{abstract}

\section{Introduction}

Public procurement has become an issue of public attention and debate, and has been subjected to reforms, restructuring, rules and regulations. Public procurement refers to the government activity of purchasing the goods and services needed to perform its functions (Arrowsmith, 2010).Odhiambo and Kamau (2003) have defined public procurement as the purchase of commodities and contracting of construction works and services if such acquisition is effected with resources from state budgets, local authority budgets, state foundation funds, domestic loans or foreign loans guaranteed by the state, foreign aid as well as revenue received from the economic activity of the state. Public procurement thus means procurement by a procuring entity using public funds (World Bank, 1995 as quoted by Kipchilat, 2006).

Procurement is a crucial element in the working functions of any state as it is used for purchasing of goods and services in the right quality, from the right source and at the right price all to meet a specific need. Every government has the obligation to provide essential services to its citizens through public procurement. Public procurement has its origins in the fiduciary obligation of government administrations to deliver goods, infrastructure and services to the population of a country or a specific geographic region, city or town (Odhiambo and Kamau, 2003).It is an important function of government for several reasons. The sheer magnitude of procurement outlays has a great impact on the economy and needs to be well managed. Indeed, in all countries in the world, estimates of the financial activities of government procurement managers are believed to be in the order of $10 \%-30 \%$ of GNP (Callender\& Mathews, 2000).

Procurement works like a pivot in the internal supply chain process turning around requests into actual products/commodities or services to fulfil the needs (Caldwell, Roehrich and Davies, 2009). Caldwell et al, (2009) further argue that procurement serves three levels of users and these are the internal customer, programs in response to emergencies and on-going programs, and prepositioning of stocks, for both internal customers and program needs.

In the entire world, every business organization depends on conversion of inputs (goods/services) into outputs both tangible and intangible that must be put in place in an effective logistical system to ensure its operations run effectively and efficiently. According to Thai (2001), the basic principles of good procurement practice include accountability, where effective mechanisms must be in place in order to enable procuring entities spend the limited resources carefully, knowing clearly that they are accountable to members of the public; competitive supply, which requires the procurement be carried out by competition unless there are 
convincing reasons for single sourcing; and consistency, which emphasizes the equal treatment of all bidders irrespective of race, nationality or political affiliation.

Kabaj (2003) concludes that an efficient public procurement system is vital to the advancement of all countries and is a concrete expression of their national commitments to making the best possible use of public resources. Non-adherence to standardized procurement processes culminates in poor co-ordination within various departments and enhances presence of leakages of financial resources, which turns out to be costly component to the whole management process of the procurement function (Knight, 2010).

In developing countries, public procurement is increasingly recognized as essential in service delivery (Basheka\&Bisangabasaija, 2010), and it accounts for a high proportion of total expenditure. For example, public procurement accounts for 58\% in Angola, 40\% in Malawi and 70\% of Uganda's public spending (Wittig, 1999; Government of Uganda, 2006) as cited in Basheka and Bisangabasaija (2010).Public procurement laws and rules have been considered as one of the most important pillars of a sound procurement system (Thai, 2009). Procurement laws and rules lead to procurement efficiency or inefficiency depending on the type of government and environment within which the system is operated. In a country where no government democracy exists, the procurement system cannot be transparent and integral (Organization for Economic Corporation and Development (OECD, 2006). According to American Bar Association (2000), a sound public procurement system needs to have good procurement laws and regulations. According to the World Bank (2006) a Public procurement system is said to be well functioning if it achieves the objectives of transparency, competition, economy, fairness and accountability.

Furthermore, in developed as well as developing countries, a sound procurement system has to accomplish two sets of requirements which are the management and policy requirements. The procurement management requirements normally include quality, timeliness, and cost, maximizing competition and maintaining integrity. The procurement policy requirements normally include economic goals for example preferring domestic or local firms, environmental protection or green procurement social goals which include assisting the minority, youth and women owned business concerns and international trade agreements. It is therefore very difficult for policy makers and public procurement practitioners to make an optimal decision as there are always tradeoffs among these goals (Thai et al, 2005). A study by the World Bank (2003a) reported that about $50-70 \%$ of the national budget (after personal emoluments) is procurement related. Therefore an efficient public procurement system could ensure value for money in government expenditure, which is essential to a country facing enormous developmental challenges.

The role of the procurement function in organizations has received and continues to receive increasing attention as the years go by. Procurement enhances efficiency and competitiveness among other benefits but to realize these benefits, it is imperative to look at the strategic factors that affect the performance of the procurement function (Harps, 2000).During the last two decades public procurement has undergone profound changes. Policy makers, academics and practitioners alike share the broad view that public procurement has evolved from a clerical signoff-ridden set of activities to a strategic tool that can enhance efficiency in public organizations, regulate markets and promote sustainable development, (Kenneth and Brian, 2006).

According to Roodhooft and Abbeele (2006), public bodies have always been big purchasers, dealing with huge budgets. Mahmood, (2010) also reiterated that public procurement represents $18.42 \%$ of the world GDP. A fully functioning police service is vital for maintenance of peace, provision of security, and enforcement of a country's law.

The weakening global economic conditions are forcing organisations to reinvent their relations with customers and suppliers alike. Thus, costs must be lowered throughout the procurement process by focusing on value addition. Bottlenecks must be removed and performance measurements focus on total system efficiency and equitable reward distribution to key players in the process; to achieve win-win situations. The working principle is to create customer satisfaction at the end point of delivery and continuous improvement of process. Procurement performance has been attracting great attention from practitioners, academicians and researchers due to poor performance. Government as a sovereign power is distinguished from commercial contracting process. In most cases, Government acts in the best interest of the public; to strive to guarantee transparency, accountability and facilitate easy access to information.

Sound public procurement policies and practices are among the essential elements of good governance (World Bank, 2005). Oriento (2007) notes that irregular procurement activities in public institutions provide the biggest loophole through which public resources are misappropriated. In some cases, tenders are awarded to firms either through single sourcing or manipulation of bids; and worse still, full payments have often been made for projects that fail to take off or are abandoned half way. Still in other cases, tenders are awarded to uncompetitive bidders through irregular disqualification of the lower bidders.

The public procurement system in Kenya was governed by amorphous legal framework such as Treasury Circulars from 1969; then Government Supplies Manual of 1978. In 1997, Government initiated the Public Procurement Reform and Enhanced Capacity Project following recommendations of two procurement 
audits carried out by consultancy firm, Society Generale de Surveillance (SGS). The audit disclosed serious shortcomings. Thus, Government decided to reform existing practices in order to achieve and enhance economy, accountability and transparency. It harmonized all rules resulting in the Public Procurement Regulations, 2001.

An Independent Procurement Review (IPR), covering selected ministries, state corporations, and educational institutions, carried out in 2005 identified further key weaknesses. Thus, Government enacted the Public Procurement and Disposal Act 2005 and in December, 2006, the Public Procurement and Disposal Regulations 2006 were gazetted to operationalise the Act, effective from 1st January, 2007. They Act was revised in 2010 and led to the development of the Public Procurement and Assets Disposal Act 2015(PPADA) which was effective from $7^{\text {th }}$ January 2016.The Act and Regulations set out rules and procedures that a procuring entity (PE) shall follow to implement procurement mandate. The aim of the Public Procurement and Assets Disposal Act 2015 was to promote fairness, transparency and nondiscrimination in procurement in public institutions with the main aim of ensuring efficient use of public funds.

Procurement methods are open tendering, restricted tendering, direct procurement, request for proposal, request for quotations, specially permitted procurement and practices for low value procurements (Procurement Act, 2005 and Procurement Regulations, 2006).The most preferred method is the open tendering as it allows for fairness and transparency. The rest are usually referred to as alternative procurement methods and should only be used where expressly allowed by the law (Procurement Act, expenditure usually depends on the procurement entity's budgetary allocation. There is need for strict adherence to these thresholds in order to remain compliant with the law, (Procurement regulations, 2006).The bodies which regulate public procurement are Public Procurement Oversight Authority (PPOA), Public Procurement Oversight Advisory Board (PPOAB) and Public Procurement Administrative Review Board (PPARB).These three can be termed as the pillars of the procurement practice in Kenya (procurement Act, 2005).

An effective public procurement system can contribute immensely to Kenya's socioeconomic development and particularly be the cornerstone of attaining the Vision 2030 Strategy.The government of Kenya is the main provider of essential services such as health, education, defense and infrastructure. This is done through procurement function, making it to be very important, and the sheer magnitude of procurement outlay has a great impact to the economy and needs to be well managed. Each country has its own economic, social, cultural and political environment and therefore, each country's public procurement practitioners face different types of challenges, indeed in all countries in the world, estimates of financial activities of the government procurement are believed to be in 10\%-30\% of GNP (Callender\& Mathews, 2005).

Efficient handling of this size of procurement outlay has been a policy and management concern as well as a challenge to procurement professionals. Rapid advancement in technology, public-private partnership, privatization, outsourcing of non-core services and increased focus on result base management in the public sector have all contributed to increased importance and sophistication of the public procurement function (O'Regan, 2009).

To manage effectively and more efficiently the procurement process, procuring entities through the existing legal framework are required to firstly consolidate departmental procurement plans to provide the entity's corporate procurement plan which before its implementation must get the accounting officer's approval. This implies that all procurement plans must be well integrated into the budget process based on the indicative budget as appropriate and in compliance with the procurement law. Agreeably Mamiro (2010) in his findings underscores these facts and concludes that one of the major setbacks in public procurement is poor procurement planning and management of the procurement process which include needs that are not well identified and estimated, unrealistic budgets and inadequacy of skills of procurement staff responsible for procurement.

According Kenyanya (2011), dissatisfaction among stakeholders brought about by loopholes left by the Regulations which may be used by dishonest people to make the process inefficient (Kenyanya, 2011). Further studies reveal that even after the enactment of the Regulations, there are losses of public funds that can be attributed to public procurement. A survey carried by the Kenya publishers association on booksellers indicates how book distributers collude with school principals to embezzle money set aside for free education in public secondary schools in Kenya (Wanyama, 2010), Kenya's public institutions have been riddled with corruption resulting in many court cases and cancellation of contracts due to allegations of irregularities in the award of such contracts (Engelbert, Reit\&Westen, 2012).Similarly, Kakwezi and Nyeko (2010) argue that procurement performance is not usually measured in most PEs as compared with the human resource and finance functions. They conclude in their findings that failure to establish performance of the procurement function can lead to irregular and biased decisions that have costly consequences to any public procuring entity. Therefore, this study was conceived by the limited scientific literature documenting the relationship between procurement performances and factors such planning, resource allocations, staff competency and political interference more specifically in public institutions in Kisii County.

\section{Statement of the problem}


Procurement is perceived as prone to corruption; occasioning waste and affecting quality of service and life improving opportunities. There is need to reverse this worrying trend and win public confidence. Despite Government efforts to improve the procurement system, it is still marred by shoddy works, poor quality goods and services (Chimwani, Iravo \& Tirimba, 2014).

Many procurement activities still suffer from neglect, lack of proper direction, poor co-ordination, slow with a lot of bureaucracy, lack of open competition and transparency, differing levels of corruption and not having a cadre of trained and qualified procurement specialists who are competent to conduct and manage the procurement process in a professional, timely and cost effective manner .According Kenyanya (2011), dissatisfaction among stakeholders brought about by loopholes left by the Regulations which may be used by dishonest people to make the process inefficient (Kenyanya, 2011).

Further studies reveal that even after the enactment of the Regulations, there are losses of public funds that can be attributed to public procurement. A survey carried by the Kenya publishers association on booksellers indicates how book distributers collude with school principals to embezzle money set aside for free education in public secondary schools in Kenya (Wanyama, 2010), Kenya's public institutions have been riddled with corruption resulting in many court cases and cancellation of contracts due to allegations of irregularities in the award of such contracts (Engelbert, Reit\&Westen, 2012). According to corruption perception index (2010) Kenya is ranked 139th out of 176 with the least corrupt countries at the top.

Effective procurement process is one in which efforts are made at all times to have a transparent and corruption free process and use of good practices (Ombaka, 2003).Public procurement has important economic and political implications by ensuring that the process is efficient and economical.

Rodin-Brown (2008) discussed the Best Practices for Designing and Implementing procurement in public institutions and How to Implement them in Developing and Transitional Countries, while Were(2014) in a study of factors affecting efficiency of the procurement function at the public institutions in Kenya analyzed institutional culture, legal framework, competency of staff and information communication technology. Waiganjo (2014) analyzed how information technology and competency of staff affected performance of procurement function. The study did not however show how procurement planning, political interference, allocation of resources and affect procurement performance. It is against this background therefore, that this research study seeks to assess the factors affecting procurement performance in public institutions in Kisii County.

\section{Objective of the Study}

The general objective of this study was to investigate the factors affecting procurement performance in public institutions in Kisii County.

\section{Specific Objectives}

The study was guided by the following specific objectives;

1. To examine the effect of procurement planning on procurement performance of public institutions in Kisii County.

2. To determine the effect of political interference on procurement performance of public institutions in Kisii County.

\section{Theoretical literature Review}

\section{Literature Review}

The following theories and models constitute the theoretical framework on which this research study is built on. Agency Theory

According to Jensen and Mackling (1976) an agency relationship is "a contract under which one or more persons (principals) engages another person (the agent) to perform some service on their behalf which involves delegating some decision-making authority to the Agent. Agency theory is concerned with agency relationships. The two parties have an agency relationship when they cooperate and engage in an association wherein one party (the principal) delegates decisions and/or work to another (an agent) to act on its behalf (Eisenhardt 2009). The important assumptions underlying agency theory is that; potential goal conflicts exist between principals and agents; each party acts in its own self-interest; information asymmetry frequently exists between principals and agents; agents are more risk averse than the principal; and efficiency is the effectiveness criterion. Two potential problems stemming from these assumptions may arise in agency relationships: an agency problem and a risk-sharing problem (Xingxing 2012).

An agency problem appears when agents' goals differ from the principals' and it is difficult or expensive to verify whether agents have appropriately performed the delegated work (i.e. moral hazard).A risksharing problem arises when principals and agents have different attitudes towards risk that cause disagreements about actions to be taken (Xingxing 2012).By their nature, buyers expect suppliers to provide good quality and to improve the quality of supplied products and/or services, but suppliers may be reluctant to invest substantially 
in quality, especially if they perceive that buyers are reaping all the benefits. The difference between buyers and suppliers will result in the two parties concerning themselves only with their self-interests (Xingxing 2012).

The agency theory is widely used in procurement, Cliff Macure and Eric Prier did a study on using agency theory to model cooperative public purchasing and the operational linkages between government organizations, their purchasers and their suppliers are vied as important contributors to the success of government policy and decision-making. Although cooperative purchasing has been a topic of study for many years (Wooten, 2003), researchers revisited issues related to cooperative public purchasing (CPP) in search of more clarification on with respect to its theoretical underpinnings (Aylesworth, 2003).

Perhaps due to little theoretical direction and few standards to guide practice, to inform on concisely about what comprises cooperative procurement and its implications for public purchasing. Indeed, John Ramsay and Nigel Caldwell (2004) make a strong case that metaphors so often used can lead to misunderstanding the nature of interesting phenomenon. It is no different in public purchasing, as slight misconceptions about institutional goals and to whom one is accountable may in fact have significant organizational consequences.

Agency theory generally assumes that actions and efforts are normally unverifiable, while outcomes are generally known and confirmable (Dixit, 2002).Consider that although the procurement official might believe that the actual purchase is an outcome," the purchase is merely considered an "action" from the viewpoint of the stakeholder for whom the purchase was made. In other words, the level of analysis is important in determining what behavior is an "action" as opposed to an "outcome."

Another reason why agency theory is a fruitful method for modelling public purchasing is that it helps to identify the various incentives of the stakeholders. By clarifying the opportunities and constraints they face, there is hope that efficiency, effectiveness and accountability will be increased. This theory explains that procurement managers in the public sector play a relationship role. According to this theory, procurement managers including all civil servants concerned with public procurement must play the agent role. Therefore procurement managers take on the role of agent for elected representatives. This theory holds that shirking is likely to occur when there is some disagreement between policy makers and the bureaucracy.

Soundry (2007) identifies this principal agent relationship among the possible risks whereby procurement managers show apathy towards principal preferred outcomes or even overriding of the principal's preferences thus resulting into non-compliance. This theory prefigures procurement regulation as an intervention whose primary purpose is to police nonconformist procurement officials resolute on 'gaming the system' to their own benefit. Taken in isolation, it paints a picture of a procurement official begrudgingly obeying procurement regulations at the pain of penal consequences, a position which is only partially correct. In the same vein, the procurement agent is seen as the primary initiator of corruption.

\section{Theory of Planned Behaviour}

The Theory of Planned Behaviour (Ajzen, 1991) is the successor of the theory of reasoned action (Fishbein and Ajzen, 1975). A central factor in the TPB is the individual's intention to perform a given behaviour. As Ajzen (1991) states, the stronger the intention to engage in a behaviour, the more likely should be its performance. According to the TPB an individual's intention to perform a given behaviour is formed by three determinants: attitude, subjective norm, and perceived behavioural control. The relative importance of the determinants varies across situations (Ajzen and Fishbein, 1980).

Attitude to certain behaviour refers to the individual's global positive or negative evaluation of performing that behaviour. Subjective norm refers to the individual's perceptions of general social pressure to perform a certain kind of behaviour. The final determinant is called perceived behavioural control. Perceived behavioural control refers to the perceived ease or difficulty of performing certain behaviour. Applied to predicting the use of competency management, the TPB holds that the extent to which an individual has a positive or negative evaluation of competency management (attitude), the perception of social pressure to use competency management (subjective norm), and the individual's confidence in his/her ability to use competency management (perceived behavioural control) will predict the intention to use and the actual use of competency management (Gelada and Ivory, 2003).

\section{The Institutional Theory}

The institutional theory is the traditional approach that is used to examine elements of public procurement (Lehmann, 2010). Scott (2004) identifies three pillars of institutions as regulatory, normative and cultural cognitive. The regulatory pillar emphasizes the use of rules, laws and sanctions as enforcement mechanism, with expedience as basis for compliance. According to Scott (2004), institutions are composed of cultural-cognitive and regulative elements that, together with associated activities and resources give meaning to life. In Kenya, public procurement is guided by the PPDA Act 2005, regulations and guidelines which are from time to time issued by the Public Procurement Oversight Authority only and which must comply with to the latter by all the public entities and providers of Public procurement regulations (2006) and guidelines directing procurement activities (Barrett, 2010). Institutional theory states that there should be compliance with Public 
procurement regulations to ensure competitive bidding, transparency, and professionalism in procurement process (Andrew, 2008).

Conceptual Framework

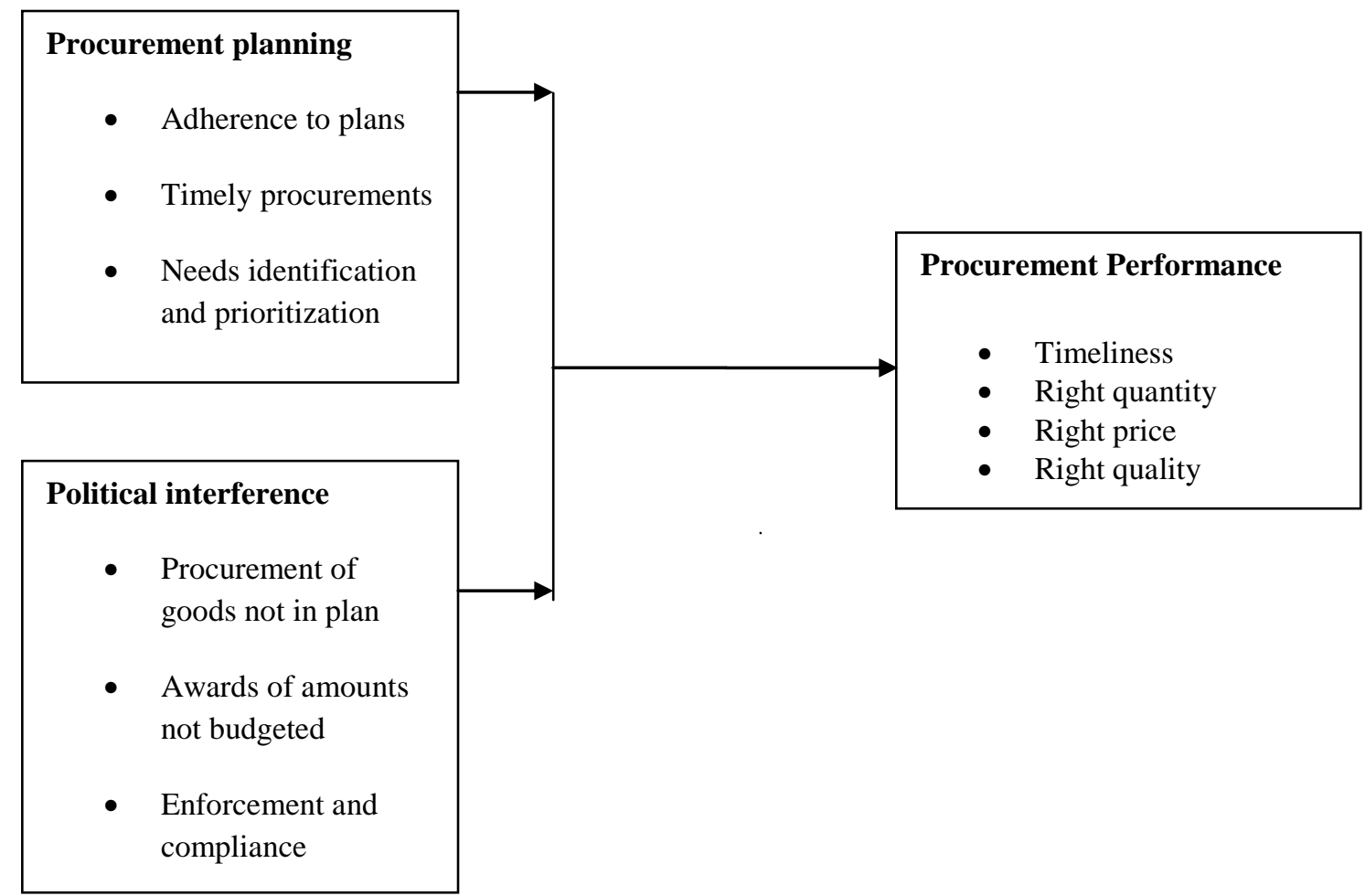

Figure 2.1 Conceptual Framework

\section{Empirical Review of Literature \\ Procurement Planning}

According to Basheka (2008) procurement planning is the primary function that sets the stage for subsequent procurement activities. According to James (2004), the ideals of planning suggest that procurement planning can be implemented in an atmosphere of complete harmony. He adds that, as a function, procurement planning endeavors to answer the questions of what do you want to procure; when to procure it; where to procure them from; when the resources be available; the methods of procurement to be use; how timely procurement or failure will affect the user of the item(s); the procuring and disposing entity; efficient in the procurement process; and the people to be involved in the procurement.

Procurement planning calls for early involvement of the purchasing office so that options and alternatives can be explored with the requesting user. Issues such as purchase estimates, product specifications, make or buy decisions, and outsourcing opportunities may very well be on the agenda. The process begins with procurement planning and ends with it after being formalized, implemented and evaluated (Drabbing\& Thai, 2003). Indeed a mistake in procurement planning has far reaching implications on each and every other function of an organization and finally impact negatively on the overall performance of the firm.

Johan, (2006) came up with some important service delivery improvement slogans. He said he who fails to plan for service delivery, plans to fail delivering services to the public. Basheka (2004) argues that procurement planning is one of the primary functions of procurement with a potential to contribute to the success of government operations and improved service delivery. It is a function that sets in motion the entire acquisition/procurement process of acquiring services in local governments. Mullins (2003) asserts that the contribution of procurement planning in facilitating an efficient and effective service delivery in public sector organizations is generally undisputed in both developed and developing countries. Mawhood (1983) further adds that effective procurement planning is an important route towards securing the right service to be delivered to the public, and also maximizing the level of service provision which can be achieved within the local Supporting People. A procurement plan helps Procuring Entities to achieve maximum value for expenditures on services to be delivered and enables the entities to identify and address all relevant issues pertaining to a particular procurement before they publicize their procurement notices to potential suppliers of goods, works and services. 
According to PPDA (2005), Public Procurement Act requires Procuring Entities to plan their procurements. A procurement plan helps Procurement Entities to achieve maximum value for expenditures and enables the entities to identify and address all relevant issues pertaining to a particular procurement before they can publicize their procurement notices to potential suppliers of goods, works and services. A procurement plan is influenced by a number of factors. These include; the value of the procurement, the type of procurement - for example, whether the procurement is sensitive, unique, high risk, or of strategic significance to the procuring Entity's success, and the nature of procurement - for example, whether it involves intrinsic risks and ethical and process issues.

Before any procurement transaction is conducted, Procuring Entities must determine their procurement needs which must be consistent with their organization's objectives. In this regard, the Procuring Entity should assess whether or not, a particular procurement is necessary. The assessment should take account of; the need to ensure that the Procuring Entity uses its resources effectively and efficiently; how the proposed expenditure would contribute to the Entity's desired outputs; and the Procuring Entity's overall procurement philosophy in accordance with the provisions of the Public Procurement and Disposal Act (PPDA, 2015).

It critical for a thorough procurement planning as firms are always facing budget constraints that cannot satisfy all capital acquisition needs (Gianakis M. 2001). According to Basheka (2008) a good procurement plan brings some sanity in the budgetary allocations and prudent financial management. Industry Manual, (2008) counsels that a procurement plan is an instrument for implementation of the budget and should be prepared by the user departments with a view to avoiding or minimizing excess votes in the entities' budgets and to ensure that procurements do not proceed unless there are funds to pay for them. This implies that all procurement plans must be well integrated into the budget process based on the indicative budget as appropriate and in compliance with the procurement law.

The UN Procurement Practitioner's Handbook (2006), further adds that, the ultimate goal of procurement planning is coordinated and integrated action to fulfill a need for goods, services or works in a timely manner and at a reasonable cost. Early and accurate planning is essential to avoid last minute, emergency or ill-planned procurement, which is contrary to open, efficient and effective - and consequently transparent procurement. In addition, most potential savings in the procurement process are achieved by improvements in the planning stages.

However, some firms continue to overlook procurement planning. The reasons for lack of procurement planning by such entities have been the actual lack of understanding of the value of procurement, proper enforcement of rules relating to planning. It could also relate to lack of capacity due to limited procurement professionals and lack of commitment and support from management of those organizations. Planning effort will succeed only with the complete commitment and involvement of top management, along with appropriate personnel that have a stake (Nantege 2011). This implies that, without thorough procurement planning, the subsequent procurement processes will not yield substantial benefits. Confusion in the whole organization may arise leading to duplication of activities and non-value adding steps with the end results being customer not satisfaction.

\section{Political Interference}

Political and bureaucratic leakage, fraud, abuse and corrupt practices are likely to occur at every stage of the process as a result of poorly managed expenditure systems, lack of effective auditing and supervision, organizational deficiencies and lax fiscal controls over the flow of public funds (Peters, et al., 2000).The ideal procurement organization must balance the desire to leverage purchasing power through complete ownership with the need to maintain the flexibility of the individual business units, functions, and regions. That balance is struck not only in the way procurement- and its accompanying processes and technologies - is structured, but in how the various roles, responsibilities, and decision rights are allocated between the corporate procurement organization and the various procurement functions attached to the business unit, functional, and regional stakeholders (Arvonen, 2002).

Leadership is the behaviors, activities, and symbolic actions of structures of formalizing for production, create social and psychological contracts, and to facilitate change in order to adapt a group into the environmental demands states Arvonen (2002). Yukl (2006) has identified different approaches of leadership. A trait approach emphasizes leaders' attributes such as personality, motives, values, and skills. Behavior approach focuses on what leaders actually do at their jobs. Power-influence approach examines influence processes between leaders and other people. It seeks to explain leadership effectiveness in terms of the amount and type of power possessed by a manager and how power is practiced. Situational approach emphasizes the importance of contextual factors that influence leadership processes. The major situational variables include the characteristics of followers, the nature of the work performed by a manager's unit, the type of organization, and the nature of external environments.

\section{Research Methodology}




\section{Research Design}

The study adopted a descriptive design. Descriptive design according to Kothari (2011) is concerned with describing, recording, analyzing and interpreting conditions that either exist or existed, using balanced panel research design. The study employed a quantitative research approach using primary data and secondary data gathered from published books and journals.

\section{Target Population}

According to Mugenda and Mugenda (2003), the target population should fit a certain specification which the researcher is studying. For the purpose of this study, the target population was 214 employees of the public institutions in Kisii County and suppliers purposively selected by the researcher. These are employees who are involved in the day to day work on procurement functions of procurement and accounting officers/in charge, who are therefore able to provide answers to the research questions.

\section{Sampling procedure and sample size}

The study took its sample frame from the employees of the 18 departments. According to Warner \&Costenoble (2011), a sample size that surpasses the threshold of 30 respondents for a normal distribution is adequate for a study. According to Mugenda\&Mugenda (2008), a sample size of between $10-30 \%$ is a good representation of the target population and hence the 30\% is adequate for analysis. From each department of either the County government or the National government three people will be targeted; an in charge, a procurement officer and a supplier making a sample size of 54.According to Best and Kaln (1998), the ideal sample should be a large enough number to serve as adequate representatives of the population and small enough to be selected economically, in terms of subject availability.

\section{Data collection procedure}

This research used primary data and secondary data. Primary data was collected by use of closed and open ended self-administered questionnaires. According to Sekeran (2009) a questionnaire is a pre-formulated written set of questions to which respondents record their answers, usually within closely defined alternatives. The questionnaires were administered using a drop and pick later approach so that the respondents have ample time to answer the questions at their own convenient time. The secondary data was attained from the written materials which included the journals, magazines, and other past studies and other relevant books on public procurement performance. This enabled the researcher to compare the data from the questionnaires with the written materials.

\section{Data Analysis and Presentation}

The collected data was thoroughly examined and checked for completeness and comprehensibility. Data collected was validated, edited and coded then analysed using descriptive statistics such as percentages and frequencies. Data was presented by the use of tables, frequency distribution tables and figures.Descriptive statistics in the form of frequencies, percentages and inferential statistics will be used for analysis in the study (Mugenda\&Mugenda, 2003). To establish the relationship between the independent variables (procurement planning and political interference) and the dependent variable of the study, inferential statistics like regression will be used in testing the hypotheses, descriptive statistics will be employed to describe andsummarize the behavior of the variables in the study.The regression analysis will be utilized in this study to determine if there is a relationship between the variables, as well as the strength of that relationship. The regression equation is:

$\mathrm{Y}=\beta_{0}+\beta_{1} \mathrm{X}_{1}+\beta_{2} \mathrm{X}_{2}+\alpha$

Where $\mathbf{Y}=$ Performance of procurement function

$\square_{\mathbf{0}}=$ =regression intercept;

$\square_{1}-\square_{2}=$ Coefficients of the model

$\mathbf{X}_{\mathbf{1}}=$ Procurement planning

$\mathbf{X}_{2}=$ Political interference

$\square=$ Random error

\section{Results And Discussion}

Descriptive statistics was used to discuss the findings of the study. The study targeted a sample size of 54 respondents from which 52 respondents filled and retuned the questionnaires making a response rate of 96.30\%.This response rate was satisfactory to make conclusions for the study as Cooper and Schneider (2003), states that a response rate of between 30 to $80 \%$ of the total sample size can be used to represent the opinion of the entire population.

\section{Procurement Planning}

Table 4.4:Procurement planning assessment factors

\begin{tabular}{|l|l|l|l|l|l|l|}
\hline Procurement planning assessment factors & & $\mathbf{1}$ & $\mathbf{2}$ & $\mathbf{3}$ & $\mathbf{4}$ & $\mathbf{5}$ \\
\hline There exists a procurement plan & freq & 0 & 0 & 3 & 6 & 27 \\
\hline & $\%$ & 0 & 0 & 8.33 & 16.67 & 75 \\
\hline There is strict adherence to the procurement plan & freq & 5 & 20 & 3 & 8 & 0 \\
\hline
\end{tabular}


Factors Affectingprocurement Performance in Public Institutions in Kenya: Asurvey of Public

\begin{tabular}{|c|c|c|c|c|c|c|}
\hline & $\%$ & 13.89 & 55.56 & 8.33 & 22.22 & 0 \\
\hline \multirow{2}{*}{$\begin{array}{l}\text { Need identification and prioritization is done before making the } \\
\text { plan. }\end{array}$} & freq & 7 & 18 & 6 & 3 & 2 \\
\hline & $\%$ & 19.44 & 50 & 16.67 & 8.33 & 5.56 \\
\hline \multirow[t]{2}{*}{ Procurements are done in a timely manner. } & freq & 21 & 13 & 2 & 0 & 0 \\
\hline & $\%$ & 58.33 & 36.11 & 5.56 & 0 & 0 \\
\hline \multirow[t]{2}{*}{$\begin{array}{l}\text { User departments are involved in the designing of procurement } \\
\text { plans }\end{array}$} & freq & 0 & 0 & 2 & 23 & 11 \\
\hline & $\%$ & 0 & 0 & 5.56 & 63.89 & 30.55 \\
\hline
\end{tabular}

This section sought to assess how procurement planning affected Procurement performance. From table 4.4 above, a majority of the respondents had a procurement plan in their institution. This is shown by $75 \%$ who strongly agree and $16.67 \%$ who agree and $8.33 \%$ who are indifferent. It is clear that most public institutions have a procurement plan in place. The findings concur with Thai (2004) who posit that there cannot be a good procurement budget without a plan, and there can be no procurement without a budget to fund it. Planning is a process that consists of many steps and the bottom line is that planning is not concerned with future decisions but rather with the future impact of decisions made today.According to PPDA (2005), Public Procurement Act requires Procuring Entities to prepare an annual procurement plan.

As to whether the respondents there were a strict adherence to the procurement plan. The findings indicate that the is no strict adherence hence departments get things not provided for in the paln. Only $22.22 \%$ of the respondents generally agree that there is strict adherence to procurement plan, while $55.56 \%$ generally disagree that there is adherence and $8.33 \%$ are indifferent. This implies that procurement plans are just drawn since they are a requirement by the various institutions.In a 2007 report, (Karin et al.) singled out non-adherence to procurement methods as a major impediment to public procurement development in Kenya. They however did not specify the stage of procurement where this happened.

A majority of respondents are of the opinion that needs identification and prioritization is not done before a plan is drawn. This is shown by $19.4 \%$ strongly disagrees and $50 \%$ disagree, while only $5.56 \%$ strongly agree and $8.33 \%$ agree, with $16.67 \%$ indifferent. This implies that very few Public Institutions carry out need identification when drafting the procurement plans.PPOA Manual(2009), states that adequate planning and prioritization of needs by each procuring entity is an essential prerequisite to effective procurement for the following reasons: Funding for procurement is unlikely to be sufficient to meet all requirements, and scarce financial resources must be allocated to meet the priority public services before less essential needs; and publication of realistic annual procurement plans allows the private sector to respond more effectively to the requirements and specifications of government, through investment in staff and equipment, manufacture and importing of goods, and financial planning. According to the (PPOA, 2009), the beginning of the procurement process is need realization and identification of the requirements. This is informed by the inventory status, projects plan, production schedules, work plans, capital or operational requirements budgets and the procurement plan.

From the table above, majority $58.33 \%$ of the respondents strongly disagree that procurement is done in a timely manner, with a further $36.11 \%$ disagreeing. $5.56 \%$ are indifferent, this agrees with Hunja (2001) and Azeem (2007) have noted that excessive documentation in public procurement is a disturbing problem that slows down the procurement process and leads to delays and boredom.

The findings of this study indicate that user departments are involved in the designing of the procurement plans. $68.39 \%$ of the respondents generally agree with a further $30.55 \%$ strongly agreeing with only $5.56 \%$ indifferent. This implies that the various departments in Public institutions take part in designing their procurement plans. The results agree with CIPS (2002) which states that it is important to involve as many people as possible from all departments for wider of the needs of each department.

Political Interference

Effect of political interference on performance of public procurement function.

Table 4.5: Political interference assessment factors

\begin{tabular}{|c|c|c|c|c|c|c|}
\hline Political interference assessment factors & & 1 & 2 & 3 & 4 & 5 \\
\hline \multirow[t]{2}{*}{ The evaluation committee is independent } & freq & 3 & 18 & 2 & 13 & 0 \\
\hline & $\%$ & 8.33 & 50.00 & 5.56 & 36.11 & 0.00 \\
\hline \multirow[t]{2}{*}{ The political class is supportive of the procurement process } & freq & 10 & 22 & 3 & 1 & 0 \\
\hline & $\%$ & 27.78 & 61.11 & 8.33 & 2.78 & 0 \\
\hline \multirow[t]{2}{*}{ Awards of tenders are outside the procurement plan } & freq & 11 & 17 & 3 & 5 & 0 \\
\hline & $\%$ & 30.56 & 47.22 & 8.33 & 13.89 & 0 \\
\hline \multirow[t]{2}{*}{$\begin{array}{l}\text { Been approached to flout the public procurement procedures and } \\
\text { regulations to protect the interest of someone. }\end{array}$} & freq & 4 & 7 & 0 & 11 & 14 \\
\hline & $\%$ & 11.11 & 19.44 & 0 & 30.56 & 38.89 \\
\hline
\end{tabular}


A majority of the respondents are of the opinion that the evaluation committee is not independent. Only $36.11 \%$ agree that the tender evaluation committee is independent. Majority of $50 \%$ disagree with a further $8.33 \%$ strongly disagreeing and $5.56 \%$ being indifferent. The evaluation committee members are meant to be independent so as to conduct a free and fair exercise. This agrees with Mamiro (2011) who says that most personnel in public institutions are unduly influenced by their seniors or bear political patronage to an individual.

From the findings in the table above, it is clear that the political class is not supportive of the procurement process. Majority of the respondents are of the opinion that the political class is supportive, 27.78\% strongly disagreeing, $61.11 \%$ generally disagreeing, and $8.33 \%$ indifferent with only $2.78 \%$ generally agreeing. That is all the elected officials; do not support procurement in public Institutions. The findings of Dorotinsky and Matsuda (2001) indicate that no matter how technically well designed; a system will ultimately prove powerless if and when politicians choose to take decisions with fiscal and budgetary implications irrespective of the quality of financial information generated.

Most public institutions seem to award tenders in the procurement plan as shown by $47.22 \%$ who agree that public institutions award tenders within the procurement plan, 30.56\% who strongly agree, a further $13.83 \%$ disagree and $8.33 \%$ are not sure. This is agrees with the Public Procurement and Disposal Act 2015 53(3) which states that Any public officer who knowingly recommends to the accounting officer excessive procurement of items beyond a reasonable consumption of the procuring entity or outside the procurement plan commits an offence under this Act.

As to whether the respondents have been approached to flout the public procurement procedures and regulations to protect the interests of someone. Most respondents are of the opinion that this is a common practice. $11.11 \%$ strongly disagree of been approached and a further $19.44 \%$ disagree, $30.56 \%$ agree on been approached with $38.89 \%$ strongly agreeing. As a government employee, you might have access to procurement and other nonpublic information that could affect a contract bid or the award process (Wymer and Regan, 2005). Improper disclosure of such protected information could violate numerous laws, as well as ethics rules.

\section{Supplier Assessment}

The effects of supplier activities on performance of public procurement in public institutions in Kisii County.

Table 4.9: Supplier assessment factors

\begin{tabular}{|c|c|c|c|c|c|c|}
\hline Supplier assessment factors & & 1 & 2 & 3 & 4 & 5 \\
\hline \multirow[t]{2}{*}{ Sometimes goods/services not budgeted for are procured } & freq & 1 & 7 & 2 & 4 & 2 \\
\hline & $\%$ & 6.25 & 43.75 & 12.50 & 25.00 & 12.50 \\
\hline \multirow[t]{2}{*}{ The institution returns goods to suppliers } & Freq & 3 & 8 & 2 & 3 & 0 \\
\hline & $\%$ & 18.75 & 50.00 & 12.50 & 18.75 & 0 \\
\hline \multirow[t]{2}{*}{$\begin{array}{l}\text { The exercise of procurement especially on tender } \\
\text { evaluation is fair and just }\end{array}$} & Freq & 5 & 6 & 3 & 2 & 0 \\
\hline & $\%$ & 31.25 & 37.50 & 18.75 & 12.50 & 0 \\
\hline
\end{tabular}

The study sought to find out whether the sometimes goods/services not budgeted for are procured. From the findings, $12.5 \%$ of the respondents strongly agree, $25 \%$ agree, $6.25 \%$ strongly disagree, $43.75 \% \%$ generally agree while $12.50 \%$ are indifferent. In most public instititutions, the goods procured are the goods in the procurement plan and emanating from the budget. This agree with Mamiro(2010) that e-procurement provide real time planning and processing hence making it difficult to procure goods and services not in the procurement plan and budget.

As to whether the institution returns good to suppliers. The study shows that $50 \%$ of the respondents generally disagree, $18.75 \%$ strongly disagree, $12.50 \%$ are indifferent and $18.75 \%$ generally agree. These shows that the tender adverts have well laid down specifications hence suppliers deliver the right quality and this leads to low goods returned to suppliers.

The exercise of procurement especially on tender evaluation is fair and just. The results in table 4.9 above suggest that $31.25 \%$ strongly disagree, $37.50 \%$ disagree, $18.75 \%$ are indifferent and $12.50 \%$ generally agree. This agrees with Singleton(2014) who states that for the procurement process to be fair,there must be a' level playing field' of all players and one should be able to look beyond the rules and regulation to ensure fairness.

\section{Regression Analysis}

The study conducted a multiple linear regression analysis to determine the relationship between independent variables and the dependent variable. The regression model was as follows:

$\mathrm{Y}=\beta_{0}+\beta_{1} \mathrm{X}_{1}+\beta_{2} \mathrm{X}_{2}+\alpha$

Where $\mathbf{Y}=$ Performance of procurement function

$\square_{0}=$ regression intercept;

$\square_{\mathbf{1}}-\square_{\mathbf{2}}=$ Coefficients of the model

$\mathbf{X}_{\mathbf{1}}=$ Procurement planning 
$\mathbf{X}_{\mathbf{2}}=$ Political interference

$\square=$ Random error

$\alpha$ is an error term at $95 \%$ confidence level.

The two independent variables that were studied, explain $68.2 \%$ of the procurement performance as represented by the $\mathrm{R}^{2}$. This therefore means that other factors not studied in this research contribute $31.8 \%$ of the procurement performance. Therefore, further research should be conducted to investigate the other factors $(31.8 \%)$ that affect procurement performance in the Public Institutions in Kisii County.

Table 4.10: Model Summary

\begin{tabular}{|l|l|l|l|l|l|}
\hline Model & R & R Square & Adjusted R Square & $\begin{array}{l}\text { Std. Error of the } \\
\text { Estimate }\end{array}$ \\
\hline 1 & $0.825 \mathrm{a}$ & 0.682 & 0.653 & 0.10056 \\
\hline
\end{tabular}

a. Dependent Variable: Procurement Performance

Table 4.11: Coefficients of Determination

Unstandard Coefficients Standardized Coefficients

\begin{tabular}{|l|l|l|l|l|l|}
\hline Model & B & Stand.error & Beta & t & sig \\
\hline (Constant) & .356 & .210 & & 1.492 & .145 \\
\hline Procurement planning & .232 & .094 & .302 & 2.675 & .002 \\
\hline Political interference & .251 & .097 & .070 & 2.026 & .004 \\
\hline
\end{tabular}

The regression equation will be;

$\mathrm{Y}=0.356+0.232 \mathrm{X}_{1}+0.251 \mathrm{X}_{2}$

The regression equation above has established that taking all factors into account (procurement planning and political interference at zero), procurement performance will be an index of 0.356 . The findings presented also shows that taking all other independent variables at zero, a unit increase in procurement planning will lead to a 0.232 increase in the scores of procurement performance. The $P$-value was 0.002 which is less than 0.05 and thus the relationship was significant.

Lastly, the study found that a unit increase in political interference will lead to a 0.251 increase in the scores of procurement performance. The $P$-value was 0.004 and hence the relationship was significant since the p-value was lower than 0.05 . The findings of the study show that, staff competence contributed most to the procurement performance.

\section{Procurement planning}

\section{Conclusion And Recommendations}

A procurement plan that is prepared annually. Procurement planning is one of the primary functions of procurement with a potential to contribute to the success of public institution's operations and improved service delivery (Basheka, 2008).The study noted that most public institutionshave procurement staffs involved in procurement plan preparation, Budgets are often reviewed to cater for changes in the economic environment and strategic plans of Public Institutions do not outline long term strategies to support the procurement systems and its processes. Lysons and Farrington (2006) also concur with the finding when they say that a cluster of reliable procedures, each comprised of a number of operations that together, provide information enabling staff to execute and managers to control operations and procedural procurement will ensure orderliness and efficiency in any procurement department.

\section{Political interference}

The study determined that the political class is not supportive of the procurement process; the public institutions have evaluation committee that are not independent, award of the tenders is within the procurement plan and some personnel had been approached to flout the public procurement procedures and regulations to protect the interests of someone. Political will is very important towards the success of the implementation as Rodin-Brown (2008) notes that successes like the Slovak Republic were the result of real acceptance, at the highest levels of the political system. According to Mzyece (2006), funding e-government programs such as eprocurement should be viewed as investments rather than merely as an expense.

\section{Recommendations}

The study is a justification of the fact that, a public institution with staff who are competent, free from political interference in the procurement process, strict adhering to procurement plans and have good resource allocation will perform effectively. The study specifically recommends that:

1. All user departments prepare a procurement plan within the set timelines. Strict adherence to the procurement plan should be done. Procurement planning is one of the primary functions of procurement 
with a potential to contribute to the success of the public institution operations. A mistake in procurement planning therefore has wide implications.

2. Procurement process should be free from political interference in public institutions. The procurement staff should be independent in the exercise of their mandate. The political class should not be given room to manipulate the process.

\section{Suggestions for further research}

The study reviewed the factors affecting procurement performance in public institutions in Kisii County and recommendation is suggested a similar study to be carried out in other Counties to find out if the same results can be obtained. Further studies may be done to investigate the effect of other factors that affect Procurement Performance in Public Institutions, for instance; ICT support and supplier evaluation.Equally, further research should be carried out in other private entities to ascertain whether these findings are universal.

\section{References}

[1]. Abagi, O. (1995) Understanding Social Research: An Overview of Nature and function of Educational Research. Nairobi: EAEP

[2]. Abbeele, A. V. D. (2006). Public procurement of consulting services Evidence and comparison with private companies. International Journal of Public Sector Management, 19(5), 490-512.

[3]. Akech, J. M. M. (2005). Development partners and governance of public procurement in Kenya: enhancing democracy in the administration of aid. International law and politics, 37(4), 829-868.

[4]. Andrew, M. (2008). Procurement Reforms in Kenya. Journal of Economics, 22(1), 23-50.

[5]. Armstrong, M. (2006). A Handbook of Human Resource Management, (10thEd.): London: Kogan Page.

[6]. Armstrong, M., and Baron, M. (1995). A Handbook of Personnel Management Practice, (6th Ed.): London: Kogan Page.

[7]. Arrowsmith, S. (2010). Public procurement: Basic concepts and coverage of procurement rules in procurement relations: An introduction. EU: Asia Inter University Network.

[8]. Arrowsmith, S., and Trybus, M. (Eds.) (2008), Public Procurement: The Continuing Revolution, Kluwer Law International, and New York

[9]. Arvonen, J. \&Pettersson, P. (2002). Leadership behaviours as predictors of cost and change effectiveness, Scandinavian Journal of Management, vol.18, pp.101- 112

[10]. Barret, P. (2010). Balancing accountability and efficiency in a more competitive public sector environment: Australian Journal of Public Administration, 59 (3), 58-70.

[11]. Basheka, B. C. (2008). Procurement planning and accountability of local government procurement systems in developing countries: International Journal of Procurement Management, 8 (3), 379- 406.

[12]. Basheka, B. C. (2012) Public procurement skills requirements framework for local government procurement professionals in Uganda: A self-perspective approach. Journal of Public Procurement, 8 (3), 379-406

[13]. Basheka, B. C. \&Bisangabasaija, E. (2010). Determinants of unethical public procurement in local governmentsystems of Uganda: a case study. Int. J. Procurement Management, 3(1), 91-104.

[14]. Basheka, B.C and Mugabira, M.I. (2008). Measuring Professionalism variables and their implication to procurement outcomes in Uganda. The 3rd international public Procurement Conference Proceedings.

[15]. Caldwell, N.D. Roehrich, J.K. and Davies, A.C. (2009), Procuring Complex Performance in Construction: London Heathrow Terminal 5 and a Private Finance Initiative Hospital, Journal of Purchasing and Supply Management.

[16]. Callendar, G. \& Mathews, D. (2000). “Government Purchasing: An Evolving Profession?" Journal of PublicBudgeting, Accounting \& Financial Management, 12 (2): 272-290.

[17]. Callender, G. \&Schapper, P. (2003). "Public Procurement Reform in Australia: A Federal-State Evaluation. International Research Study of Public Procurement.” In Proceedings of International Research Study of Public Procurement (pp. 48-61), 10-12 April, Budapest, Hungary.

[18]. Cronbanch. N. (2011) Regulating Procurement Practice, 4th edition. New York: Jaico Publishing House

[19]. Eisenberger, R., Armeli , S., Rexwinkel, B., Lynch, P., \& Rhoades, L. (2002). Reciprocation of Perceived Organizational Support. Journal of Applied Psychology (86), 42-51.

[20]. Eisenberger, R., Cumming, J., Armeli, S., \& Lynch, P. (1997). Perceived Organizational Support, Discretionary Treatment and Job Satisfaction. Journal of Applied Psychology (82), 812-820.

[21]. Errigde, A. \&Mcllroy, J. (2002). 'Public procurement and supply management strategies', Public policy and administration, volume 17, No.1, spring, pp 52-71.

[22]. Government of Kenya (2005). The Public Procurement and Disposal Act No. 3 of 2005. Kenya Gazette Supplement No. 77(Acts No. 3)

[23]. Harps L. H. (2000). "The Haves and the Have Nots": Supply Chain Practices for the New Millennium: Inbound Logistics Journal. 75-114.

[24]. Kabaj, O. (2003). The Challenge of African Development, Oxford University Press: New York.

[25]. Kenyanya, N., Mamati, W. and Onyango, J. (2011). Evaluation of the influence of the public Procurement Regulations on procurement Practices among Secondary Schools in Mosocho division, Kisii County, Kenya. Research paper Egerton University.

[26]. Kioko, N. J. \& Were, S. (2014). Factors affecting efficiency of the procurement function at the public institutions in Kenya, A case of Supplies Branch in Nairobi. International Journal of Business \& Law Research 2(2), 1-14.

[27]. Kipchilat, G.T. (2006). An Evaluation of the Impact of the Public Procurement Regulations on Procurement in Kenyan Public Universities. Unpublished MBA Project, Egerton University, Nakuru Kenya.

[28]. Kipkorir, J. (2013). The role of proactive procurement on strategic procurement performance at public institutions in Kenya: a survey of Rongai sub-county in Nakuru county, International Journal of Social Sciences and Entrepreneurship, 1 (3), 102-115.

[29]. Knight, L., Harland, C., Telgen, J., Caldwell, N. (2010) Public Procurement International Case and Commentary, Routledge, London.

[30]. Kombo. K.D. and Tromp A.L.D. (2011). Proposal and thesis writing .Nairobi: Pauline's Publication Africa.

[31]. Kothari, C.R. (2004), Research Methods and Techniques, New Age Publishers, New Delhi.

[32]. Kothari, C.R. (2011). Research Methodology: Methods and Techniques. (2nd Revised Ed.), New Delhi: New Age International (P) Limited. 
[33]. Mahmood, S. A. I. (2010). Public procurement and corruption in Bangladesh. Confronting the challenges and opportunities. Journal of public administration and policy research, 2(6), 103-111.

[34]. McCrudden, C. (2008), "Using public procurement to achieve social outcomes”, Natural Resources Forum, Vol. 28 No. 4 pp. 257 67.

[35]. Mugenda, O. M., \&Mugenda, A. G. (2003). Research methods: Quantitative and qualitative approaches. Nairobi: Acts Press.

[36]. Mugenda, O. \&Mugenda, A. (2008). Social Science Research: Theory and Principles. Nairobi: Acts Press.

[37]. Odhiambo, W and Kamau, P (2003) The integration of developing countries into the world trading system. Public procurement lessons from Kenya, Tanzania and Uganda, available on http:/www.oecd.org, on 15th Dec. 2009.

[38]. Ombaka E. (2003). Management of medicines procurement in Developing countries. Accessed online at <http//health-careprocurement.com/content/pdf/1689-2231-6-8.pdf>

[39]. O'Regan, N. \&Ghobadian, A. (2009), 'Testing the homogeneity of SMEs. The impact of size on managerial and organizational processes: European Business Review, 16 (1), 64-79.

[40]. Onyinkwa, J. (2013). Factors influencing compliance to Procurement regulations in public secondary schools in Kenya. A case of Nyamache District, Kisii County. Interdisciplinary Journal of Contemporary Research in Business, Vol. 5 No.1,pp.561-592

[41]. Raymond, J. (2008). Benchmarking in public Procurement. Benchmarking: An International Journal, 15(6),782-793.

[42]. Saunders, M. Lewis, P. \& Thornhill, A. (2003). Research Methods for Business student, (3rd Ed), Harlow: Pearson Education.

[43]. Saunders, M. \& Thornhill, H. (2009). Research Methods for Business Student: Benelux BV New Hall.

[44]. Sekaran, U. (2009). Research Methods for Business: A Skill Building Approach (4th Ed.). New Delhi: wiley-India

[45]. Thai, K.V. (2001). "Public procurement re-examined", Journal of Public Procurement, Vol. 1 No.1, pp.9-50.

[46]. Thai, K. V. (2004). Introduction to Public Procurement, (5th edition). Florida Atlantic University.

[47]. Thai, K. V. (2006). Advancing public procurement practices. Thai, K.V and Piga, G. Innovations and knowledge sharing (ch.1), Pr Academics Press.

[48]. Thai, K. V. (2009). International Handbook of Public Procurement: CRC, Pross, Taylor and Francis Group.

[49]. Waiganjo, J. W., Mukulu, E., \&Kahiri, J. (2014). Relationship between strategic human resource management and firm performance of Kenya's corporate organizations: International Journal of Humanities and Social Science, 2(10), Special Issues.

[50]. Wanyama, J. (2010). The effectiveness of the Procurement Regulations in Kenya. Available on http:/www.oecd.org, on 23rd October, 2013.

[51]. Were S. (2014). Factors Affecting Efficiency of the Procurement Function at the Public Institutions in Kenya (A Case of Supplies Branch in Nairobi). International Journal of Business and commerce,3(1),54-70.

[52]. Witting, W. A. (1999). Building value through public procurement, A focus on Africa: Durban: 9th international anti- corruption conference, 10-15 October. Durban: South Africa

[53]. World Bank (2003). World Development Report 2003: Equity and Development, Oxford University Press, New York, NY,

[54]. Xingxing, Z. \&Kaynak.H. (2012). An agency theory perspective on supply chain quality Management. International Journal of Operations and Production Management, 32 (4), 423-446. 